\title{
DEVELOPMENT OF REAL TIME POLYMERASE CHAIN REACTION FOR DETECTION OF Salmonella typhimurium AND Salmonella enteritidis IN FISH
}

\section{Pengembangan Real Time PCR untuk Mendeteksi Keberadaan Salmonella tyhpimurium dan Salmonella enteritidis pada Ikan}

\author{
Tuti Hartati Siregar ${ }^{1)^{*}}$, Jennifer Elliman ${ }^{2)}$ and Leigh Owens ${ }^{2)}$ \\ 1) Research and Development Centre for Marine and Fisheries Product Processing and Biotechnology, Indonesia \\ 2) James Cook University, Australia \\ *Correspondence Author: toetihs@yahoo.com. KS. Tubun Petamburan VI Jakarta Pusat 10260
}

\begin{abstract}
Previously designed endpoint PCR has been adapted for use with real time PCR to detect the presence of Salmonella typhimurium and Salmonella enteritidis in fish. Optimization of a standard curve in the presence of herring sperm DNA as background matrix indicated that the real time PCR highly efficient with the Pearson coefficient of determination $\left(R^{2}\right)$ value $=0.99937$ and slope (M) value $=-3.44$. An enrichment method (overnight culture) significantly increased $(p<0.05)$ the sensitivity of real time PCR. Comparison of real time PCR and the conventional isolation method based on biochemical tests has been conducted. In terms of their sensitivity, real time PCR and the conventional methods are not significantly different in the level of confidence $95 \%$. Both real time PCR with enrichment method and conventional biochemical method can detect the presence of Salmonella spp. in spiked sample. However the direct extraction method was only detecting the presence of Salmonella in higher concentration. While the sensitivity both conventional and real time PCR are similar, the real time PCR has an advantage to detect the pathogen qualitatively and quantitatively depending on processing method.
\end{abstract}

Keywords : real time PCR, Salmonella contamination, fish

\begin{abstract}
Abstrak
Desain PCR terdahulu yang dimodifikasi telah digunakan untuk mengembangkan metode real time PCR untuk mendeteksi keberadaan Salmonella typhimurium dan Salmonella enteritidis pada ikan. Optimasi kurva standar real time PCR dengan menggunakan DNA sperma ikan herring sebagai latar belakang matriks menunjukkan kondisi real time PCR yang telah didisain mempunyai efisiensi yang tinggi dengan nilai $R^{2}=0.99937$ dan $M=-3.44$. Metode pengayaan kultur dengan inkubasi selama 24 jam dapat meningkatkan sensitivitas real time PCR secara signifikan $(p<0,05)$. Perbandingan antara metode real time PCR dengan metode konvensional berdasarkan reaksi biokimia juga telah dilakukan. Berdasarkan hasil analisis statistik dengan tingkat kepercayaan 95\%, sensitivitas antara real time PCR dengan metode konvensional terlihat tidak berbeda nyata. Baik metode konvensional maupun metode molekular dengan cara pengayaan kultur dapat mendeteksi keberadaan Salmonella sp. Sementara metode real time PCR tanpa pengayaan kultur hanya dapat mendeteksi keberadaan Salmonella pada konsentrasi yang cukup tinggi. Walaupun sensitivitas tidak berbeda nyata secara statistik, real time PCR mempunyai keunggulan dibanding metode konvensional karena mampu melakukan kuantitasi terhadap sampel sementara metode konvensional hanya mampu melakukan uji kualitatif.
\end{abstract}

Kata Kunci : real time PCR, kontaminasi Salmonella, ikan

\section{INTRODUCTION}

Fisheries products are one of the vital resources in many countries that have open seas or aquaculture activities such as Australia, Japan, Norway, Indonesia, Vietnam, and Thailand. Consumption of fisheries protein increases each year and is the second only to animal products in consumption. Based on statistical data from FAO, fish demand increases each year due to its high protein and low fat and fresh fish demand is still the highest among all fishery products (FAO, 2011).

The main problem of fisheries product marketing not only comes from pre-harvesting such as antibiotic residue but also post-harvesting which mostly due to hygiene. Most importer countries require high standards of food safety from aquaculture to 
consumption. The food safety analysis includes the presence of pathogens, antibiotics to prevent aquaculture diseases, and processing activities (Hutagalung, 2012). Salmonella spp. is the second most common pathogen in fish after Vibrio parahaemolyticus. The presence of Salmonella in fishery products especially from aquaculture is due to lack of sanitation and causes product rejection by importers (Hutagalung, 2012). Therefore, testing before exporting the product to countries such as USA, Japan, and European Union countries is an essential part of the production chain.

Basically, there are two methods to detect the presence of Salmonella in food. The most common method is the conventional method, which is based on biochemical reactions while the molecular method is based on DNA amplification. The conventional method has been considered as "gold standard" for both pathogen isolation and identification. The conventional method is considered easier, but less sensitive, less specific, and slower than molecular methods (Voogt et al., 2001; Wilkins et al., 2010; Techathuvanan et al., 2011; Zhang et al., 2011). PCR has many variations including endpoint and real-time PCR, and detection based on DNA or RNA. Information regarding comparison of conventional method and molecular method to detect Salmonella in food has been derived from multiple studies (Kumar et al., 2008; Mafu et al., 2009; McCabe et al., 2011; Zhang et al., 2011). The presence of pathogens from different types of samples such as environment, food, and clinic also have been studied. Although there is some research in developing PCR for fish and fishery products (Kumar et al., 2003; Kumar et al., 2008; Kumar et al., 2010), most PCR development has been done for food samples from non-fishery products. Real time PCR is a more recently developed technique compared to endpoint PCR. This new generation of PCR adds an optical module which allows it to detect the target DNA replication during each PCR cycle through detecting its fluorescent signal (Mackay, 2004). Therefore, gel electrophoresis is no longer needed to be performed to detect the DNA product. Due to its more recent development, information about how this PCR performs to detect the presence of Salmonella in food, especially in fish and fishery products, is still rare. Developing a real time PCR method for Salmonella identification is important for Indonesia because its development for food pathogen analysis is still not common yet.

PCR methods have been developed for targeting different genes of Salmonella. Compared to traditional culture methods or conventional methods as stated before, PCR methods have been reported as more rapid, specific, and sensitive (Croci et al., 2004; Catarame et al., 2006; Eriksson \& Aspan, 2007; Wilkins et al., 2010; G. Zhang et al., 2011). However, not all PCR methods are able to detect all species and serotypes of Salmonella. Numerous gene targets such as himA, invA, stn, hns, spvC, oriC, ompC, fimC, agfA, sefC, misL, phoP, and $p h o Q$ have been studied (Rahn et al., 1992; Malorny et al., 2004; Soto et al., 2006; Zhang et al., 2011; Craciuna et al., 2012). The PCR targeting the invA gene (Rahn et al., 1992; Kumar et al., 2008) has been reported to identify all serotypes of Salmonella spp. and was selected for adaptation to a real time PCR and further analysis of its use with fisheries products.

Conventional analysis of food products for the presence of Salmonella serotypes includes enrichment steps. PCR methods may also require this step to allow pathogens growth and present in high concentrations prior to nucleic acid extraction, which can be a limitation (Zhang et al., 2011). This condition, of course, delays the analysis time and reduces the power of PCR in terms of its rapid analysis when the result is needed immediately, especially during an outbreak. In addition, enrichment complicates the quantification of pathogens. Therefore, in this research comparison of direct extraction and indirect with overnight enrichment methods were conducted to study the differences between those two extraction methods to the real time PCR performances, as well as comparing the PCR methods to conventional protocols.

\section{MATERIALAND METHODS}

\section{Materials}

Salmonella typhimurium ATCC 14028 used in this research was obtained from James Cook University (JCU) bacterial collection and Salmonella enteritidis ATCC 13026 was purchased from Abacus ALS, and kept at JCU bacterial collection. Primers InvA-R and InvA-F (5'- GTGAAATTATCGCCACGTTCGGGCAA3 ' and 5'- TCATCGCACCGTCAAAGGAACC -3') were used with qPCR gotaq master mix (Promega). DNA was extracted using a Wizard DNA purification kit (Promega). Fish was purchased from local supermarket in Townsville, Australia.

\section{Sample Preparation}

Fish meat without bone $(10 \mathrm{~g})$ was spiked with Salmonella from high concentration $\left(3.04 \times 10^{7} \mathrm{cfu} / \mu \mathrm{l}\right)$ to below expected detection limit $\left(3.04 \times 10^{3} \mathrm{cfu} / \mu \mathrm{l}\right)$. Ninety $\mathrm{ml}$ of diluent was added, then the sample was stomached for two min and $5 \mathrm{ml}$ of that sample was removed for total DNA extract into a final volume of $100 \mathrm{ml}$.

The concentration of Salmonella spiked in fish samples was divided into three groups, low, middle 
and high. The amount of Salmonella in the lowest group was $3.04 \times 10^{3}$, middle is $3.04 \times 10^{5}$ and the highest was $3.04 \times 10^{7} \mathrm{cfu} / \mu \mathrm{l}$. Overnight culture was obtained from overnight incubation of Salmonella in Rapavort-Vassiliadis (RV) broth. One ml of sample was transferred into RV broth and incubated at $44^{\circ} \mathrm{C}$ overnight. After incubation, $1 \mathrm{ml}$ of sample from RV broth was extracted using the same DNA extraction method. Direct extraction method was prepared directly after stomached. Control of sample was prepared as sample preparation without Salmonella addition.

\section{DNA Extraction and Purification}

One ml of sample of either overnight Salmonella culture or stomached fish sample was processed using a commercial DNA extraction kit (Wizard DNA purification kit, Promega) according to manufacturer's instructions. DNA concentrations $(\mathrm{ng} / \mathrm{\mu l})$ and purity $\left(A_{260} / A_{280}\right.$ ratio) were determined using a spectrophotometer (Implen, Germany). The copy number/ $\mu$ l calculated based on a genome size of Salmonella ATCC 14028 (http://www.uri.edu/research/ gsc/resources/cndna.html).

\section{Condition of Real Time PCR and DNA Analysis}

Cycling conditions as stated in Table 1. were adapted from reported standard PCR protocols for invA (Rahn et al., 1992; Kumar et al., 2008) using an initial hold step suitable for the brand of DNA polymerase used (Promega). Salmonella DNA was analysed using real time PCR at the same condition as stated in Table 1.

\section{Standard Curve Development}

The Salmonella DNA was diluted using either water or $5 \mathrm{ng} / \mu \mathrm{l}$ herring sperm DNA in water. Serial dilution from $10^{-1}$ to $10^{-8}$ was made and analysed in quadruplicate with real time PCR (Rotor Gene Q series) to obtain a Salmonella concentration standard curve. Each PCR run contained quadruplicate no template control (NTC) samples as well as Salmonella samples. The sensitivity of the PCR was determined using serial dilution from $10^{-1}$ to $10^{-8}$ of the Salmonella typhimurium DNA.

\section{Conventional Method to Identify the Pres- ence of Salmonella in Fish}

One loop of overnight culture of Salmonella was transferred by streak plating to xylose-lysindeoxychocolate (XLD) agar. Plates were incubated overnight at $37^{\circ} \mathrm{C}$. The XLD result was observed after 18-24 $\mathrm{h}$ incubation and the number of positive and negative results were recorded.

\section{Data Analysis}

Signal from PCR was converted by the real time PCR software into concentration (cfu/ $\mu \mathrm{l})$. Positive sample from conventional method was confirmed by the presence of pink with black centre of colonies typical for Salmonella. Statistical analysis was performed using crosstabs chi-square and a two way ANOVA (IBM SPSS program).

\section{RESULT AND DISCUSSION}

\section{Condition of Real Time PCR and Standard Curve Development}

Primer set invA was used to analyse pure Salmonella typhimurium and Salmonella enteritidis. The product of PCR with the invA primer produce single melt curve peak (Fig. 1).

DNA extracts of Salmonella typhimurium ATCC 14028 were determined to be $80 \mathrm{ng} / \mu \mathrm{l}$. This corresponds to a copy number of $1.52 \times 10^{7} \mathrm{copies} /$ $\mu$ l. Dilutions with corresponding copy numbers are listed in Table 2.

Standard curve and detection limit analysis were determined using two diluents, water, and herring sperm. The linearity between threshold values $(\mathrm{Ct})$ and Salmonella concentration was observed in 10 fold dilution series from $10^{-1}$ to $10^{-8}$ (Fig. 2). The lowest detection limit of the observed real time PCR was $10^{-6}$ in water diluent, ten fold higher than in herring sperm diluent which was only $10^{-5}$. However, $R^{2}$ values for herring sperm was 0.99937 , slightly better than $R^{2}$ values in water dilution which was only 0.99594 . The efficiency of PCR reaction can also be determined from the slope (M value). The highest efficiency (100\%) can be achieved from $M$ value of $-3.3 \pm 10 \%$ ( $A B$,

Table 1. Real time PCR cycling condition 


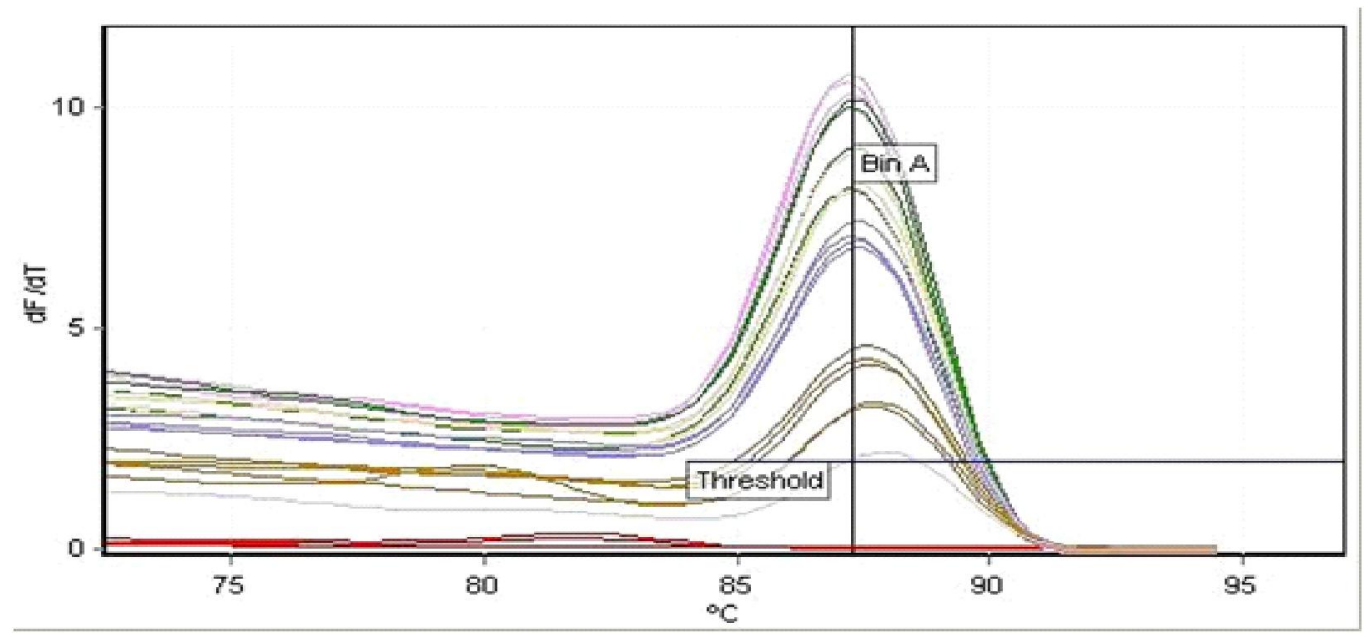

Figure 1. Melt data for standard curve with invA primer

Table 2. Number of DNA copies expected in each 10 fold dilutions

2011). The $M$ value for the herring sperm standard was -3.44 which more acceptable in the range of ideal $\mathrm{M}$ value compare to the water standard -3.55 .

The presence of herring sperm DNA as background DNA in the standard curve lowered the actual detection limit 10 fold due to the additional matrix of the herring sperm DNA. The ability of the invA primer to find Salmonella DNA was decreased by the presence of background non-template DNA. However, since any DNA extraction from a fish sample will contain a DNA sample matrix which contains fish DNA, use of Herring sperm DNA in the standard curve results in a matrix more similar to the fish sample than the use of water alone as a diluent. Thus the standard curve in herring sperm serial dilution with a detection limit of $1.52 \mathrm{x}$ $10^{2} \mathrm{copies} / \mu \mathrm{l}$ was chosen for future work. The inv $A$ primer-herring sperm standard also worked for both Salmonella serotypes equally. The efficiency of the herring sperm standard curve was very good $\left(R^{2}=0.99937\right.$ and $M$ value -3.44$)$ indicating this $q P C R$ is a good basis for further work.

\section{Development of PCR to Identify Salmonella in Artificially Contaminated Fish}

Results of PCR analysis showed that the concentration signal from overnight culture was slightly increased compared to direct extraction for either Salmonella typhimurium or Salmonella enteritidis as can be seen from Figure 3. The result of ANOVA analysis from IBM SPSS Statistical 20 program determined that overnight.

The conventional method of Salmonella identification in food uses $25 \mathrm{~g}$ of food product with $225 \mathrm{ml}$ of diluents, to make a final volume of $250 \mathrm{ml}$ (a $1 / 10$ dilution). That $25 \mathrm{~g}$ of sample is used to increase the likelihood of including any contaminating Salmonella in the sample taken. For this study, $10 \mathrm{~g}$ in a total of $100 \mathrm{ml}$ diluent was used (also $1 / 10$ dilution) as all samples were spiked with known amounts of Salmonella and detection limit could be determined that can be converted to $25 \mathrm{~g}$ samples mathematically. This meant less media ( $10 \mathrm{~g}$ in $100 \mathrm{ml}$ diluent) was 

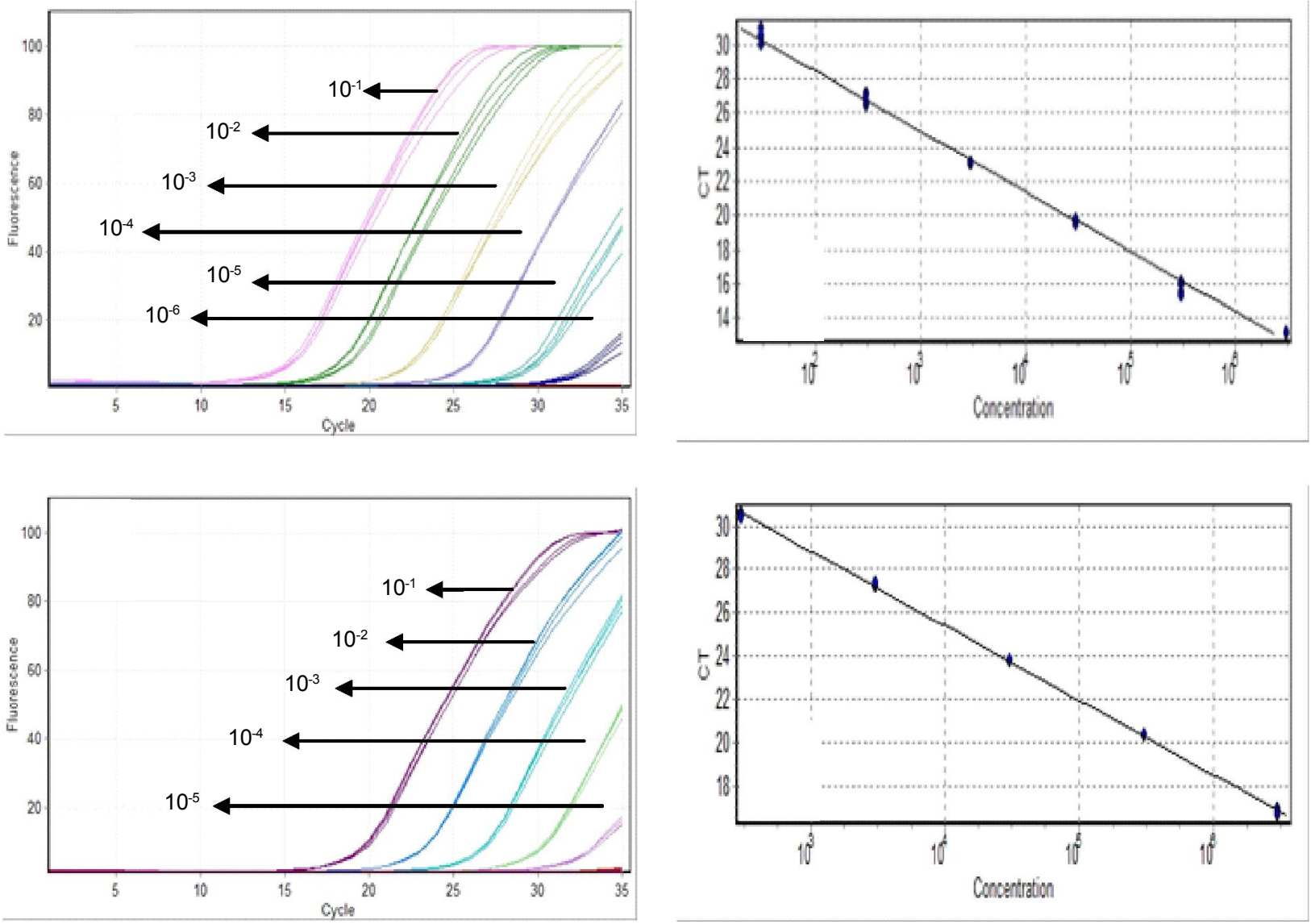

Figure 2. Standard curve and sensitivity of invA primer for Salmonella typhimurium (A) in water dilution and (B) in herring sperm dilution. $\mathrm{CT}=$ threshold value and concentration was in $\mathrm{cfu} / \mathrm{ml}$.

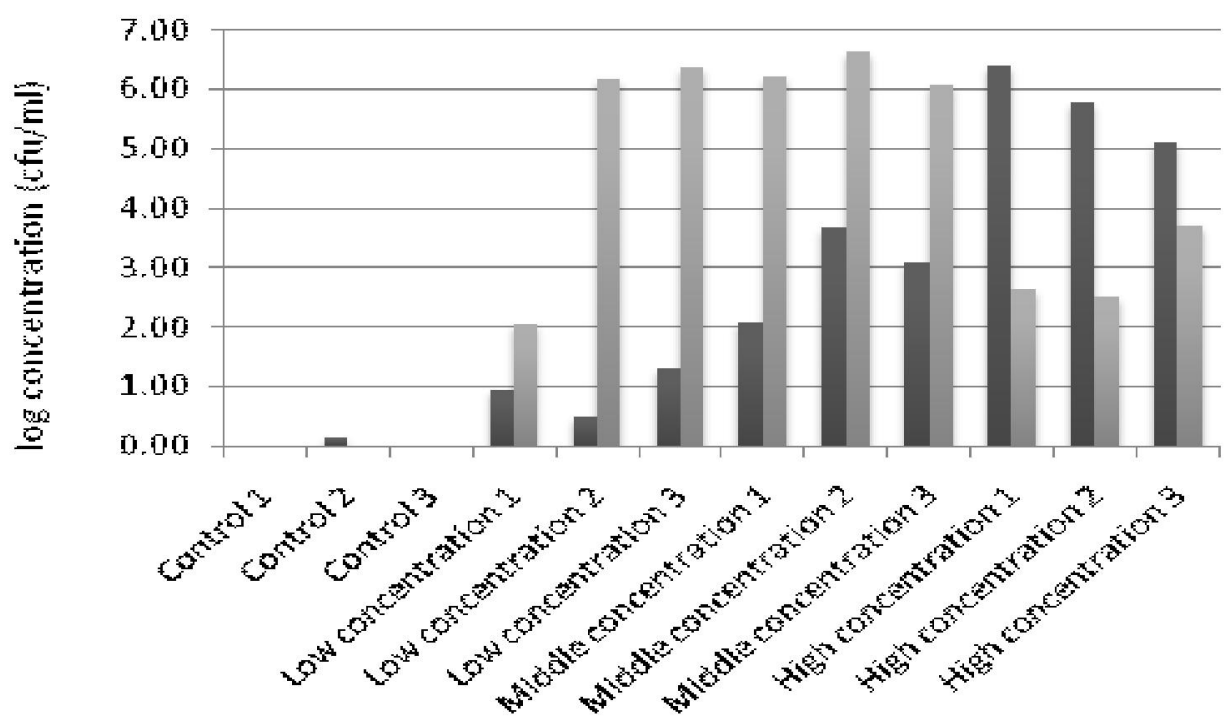

- Dir ect

overnight

Figure 3. Log concentration of Salmonella typhimurium with direct extraction and overnight culture using real time PCR assay. Samples were processed in triplicates; 
required rather than using $25 \mathrm{~g}$ fish in a total of $225 \mathrm{ml}$ diluent. However, standard for food analysis is required ( $25 \mathrm{~g}$ sample in $225 \mathrm{ml}$ diluents).

Direct extraction of both Salmonella typhimurium and Salmonella enteritidis (data not shown) tends to produce lower concentrations compared to their extraction after overnight culture. Statistical analysis shows that the differences are significant in the 95\% level of confidence. This is expected as it is reasonable that during incubation time, Salmonella grow rapidly which increases the chance to extract higher copy numbers of DNA.

The presence of false-positive or false-negative results were occured. If lower concentrations (serial dilution below the identified standard curve detection limit) had been trialled, the direct method might show to have a lower sensitivity due to the inability of the PCR to detect small amounts of DNA target among all background matrix, thus resulting in falsenegatives. PCR also might lead to false-positives due to over-estimation of DNA target or viable cells among mixed populations of other background DNA (Lungu et al., 2012), although the InvA endpoint PCR has been previously tested for specificity and found to be specific to Salmonella (Rahn et al., 1992). One direct DNA extraction and overnight culture gave 30 out of 48 and 36 out of 48 positive results, respectively. As can be seen from Figure 4, both conventional and molecular overnight method produced similar results while the molecular direct method had the less number of positive results.

The data displayed in Figure 4 was analysed by using SPSS crosstabs chi square (IBM SPSS statistic 20) to determine the statistical differences between the conventional method and the direct molecular method and the differences between both molecular methods (data not shown). In both cases no statistical difference was found between the results of each method.

Samples used in real time PCR using overnight culture and the conventional methods were prepared identically prior to DNA extraction or plating. Both were prepared from overnight culture which allowed Salmonella to grow rapidly. The result from Figure 4 shows that both conventional and PCR method using overnight culture produced similar results. Both methods were able to detect the presence of Salmonella from the lowest concentration of spiked fish $\left(3.04 \times 10^{3} \mathrm{cfu} / 10 \mathrm{~g}\right.$ fish) after $24 \mathrm{~h}$ incubation. In other word, both methods detected positive samples

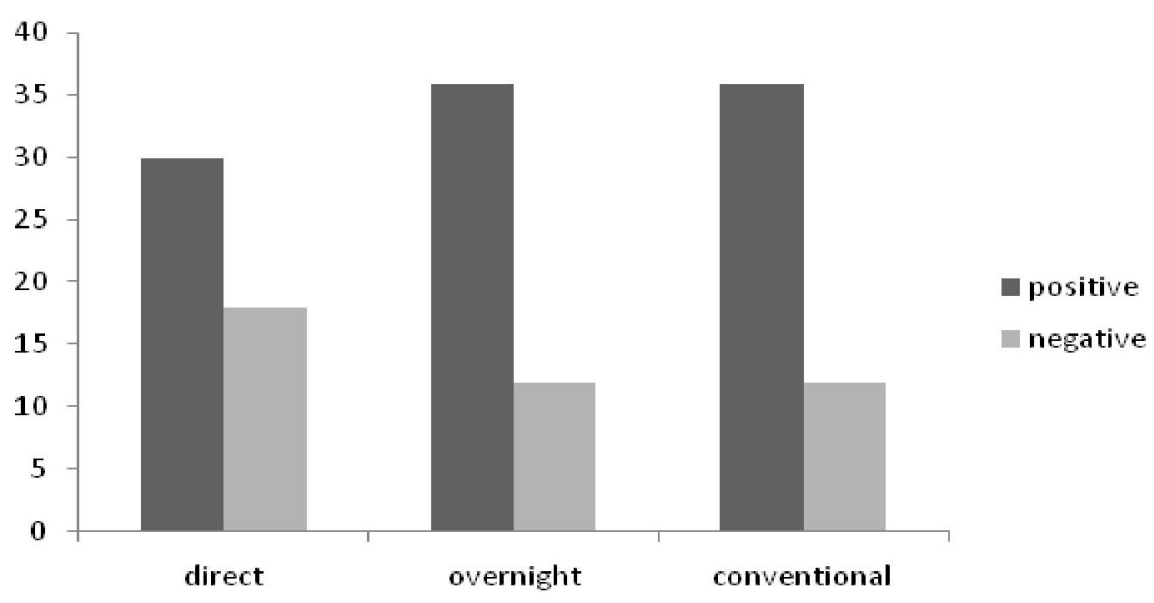

Figure 4. Comparison of positive vs negative results for real time PCR and conventional methods

suggested solution to the possibility of detecting nonviable Salmonella DNA is to detect RNA via RT-PCR (Zhang et al., 2011), however this posses other issues and increases the detection time.

\section{Comparison of Real Time PCR vs Conven- tional Method}

Thirty six out of 48 samples which were analysed with the conventional method showed positive results of non-lactose fermenting, black centred colonies, typical for Salmonella spp. The molecular method with
$100 \%$ of the time since the 12 negative results were from unspiked negative control samples. There were less positive results from the molecular method using directly extracted DNA and the concentrations were lower compared to those methods using overnight culture. This is expected as the overnight enrichment results in Salmonella replication, thus increasing to numbers. While there are numerical differences, based on statistical analysis, there is no significant different either between conventional method and molecular method using direct DNA extraction or between both molecular methods with different protocols for DNA 
extraction. Therefore, if there is any difference between those methods, it can only happen by chance.

Additional samples were spiked below the direct detection limit in which resulting statistical differences were being identified, but based on the current statistical result analysis of Salmonella in fish can be faster if sample DNA is extracted by using the direct technique. This technique is very useful to cut the time that consumed by overnight enrichment for the PCR method or several days for biochemical testing with conventional method. This is especially important during an outbreak of food borne. The fastest analysis is really important since the result is needed as soon as possible to take further action.

The direct extraction method also measures the actual number of Salmonella in the fish sample. Incubation overnight allows Salmonella to grow rapidly which causes the number of Salmonella when it is analysed the next day to be much higher. The sensitivity of PCR relative to original dose will be better when the overnight culture is run compare to the direct method because the number of extracted DNA will be far higher. Current standards state that no Salmonella can be present in food (Australian Standard, 2009). As the conventional method and overnight enrichment PCR both detected all positively spiked samples in this experiment, it would be useful to carry out a comparison of conventional versus molecular methods at increasingly lower spiking doses to determine at what point each method does not detect Salmonella. This would determine the limits of each method. Based on Oxoid media description, the detection limit for Salmonella precise method is $0.1-1.8 \mathrm{cfu} / 25 \mathrm{~g}$ (Oxoid, UK).

Even though the conventional method, based on doses spiked, is similar with the indirect PCR method in terms of its sensitivity, the direct PCR method has more advantages. The conventional method only identifies presence/absence of Salmonella while quantification using overnight culture for indirect PCR does not correlate with initial spiked doses. On the other hand, while not as sensitive, the direct PCR method can detect the concentration of the pathogen in samples.

\section{CONCLUSION}

In summary, the DNA extraction method influences the ability of real time PCR to detect the presence of Salmonella typhimurium and Salmonella enteritidis in fish. Direct DNA extraction from fish without enrichment can speed the analysis up to one day. However the enrichment method allows bacteria to grow which increases the number of viable cells and improves the ability of real time PCR to detect contaminated samples. The real time PCR method has similar sensitivity to the conventional method in terms of positive and negative detection for the doses analysed. However it has more value when the quantity of Salmonella is desired. The direct technique of DNA extraction followed by PCR analysis is the fastest way to analyze pathogen in fish and the result is not statistically different compared to the conventional and real time PCR method with overnight culture technique. Further tests at lower doses of Salmonella would be useful to quantify the actual detection limits of each method.

\section{REFERENCES}

AB. 2011. Real time PCR: understanding Ct. In A. Biosystem (Ed.), Real time PCR: Life Technologies. Australian Standard. 2009. Method 10: Microbiology of food and animal feeding stuffs-Horizontal method for the detection of Salmonella spp. (ISO 6579:2002, MOD) Food Mirobiology (pp. i-iv, 1-44). Sydney, NSW, Australia: Standards Australia Limited.

Catarame, T. M. G., O'Hanlon, K. A., McDowell, D. A., Blair, I. S., and Duffy, G. 2006. Comparison of real-time polymerase Chain Reaction assay with a culture method for the detection of Salmonella in Retail Meat Samples. Journal of Food Safety. 26(1): 1-15. doi: 10.1111/j.1745-4565.2005.00025.x

Craciuna, C., Keul, A.-L., Flonta, M., and Cristea, M. 2012. DNA-based diagnostic tests for Salmonella strains targeting hilA, agfA, spvC and sef genes. Journal of Environmental Management. 95 (Suppl. 0): S15-S18. doi: 10.1016/j.jenvman.2010.07.027

Croci, L., Delibato, E., Volpe, G., De Medici, D., and Palleschi, G. 2004. Comparison of PCR, electrochemical Enzyme-Linked Immunosorbent Assays, and the standard culture method for detecting Salmonella in meat products. Appl. Environ. Microbiol.70(3): 1393-1396. doi: 10.1128/ aem.70.3.1393-1396.2004

Eriksson, E. and Aspan, A. 2007. Comparison of culture, ELISA and PCR techniques for salmonella detection in faecal samples for cattle, pig and poultry. BMC Vet Res. 3(1): 21.

FAO. 2011. Fisheries and Aquaculture Statistic Food Balance Sheets. Retrieved from ftp://ftp.fao.org/Fl/ CDrom/CD_yearbook_2009/navigation/ index_content_food_balance_e.htm. Accessed at 26 July 2012

Hutagalung, S. 2012. Indonesian Fisheries Products Merit European Union Standard. Retrieved from http:/ /ri.co.id/index.php/detailberita/detail/ 20224\#.UDuCI6PYTTI. Accessed at 27 July 2012

Kumar, R., Surendran, P. K., and Thampuran, N. 2008. Evaluation of culture, ELISA and PCR assays for the detection of Salmonella in seafood. Letters in Applied Microbiology. 46(2): 221-226. doi: 10.1111/j.1472765X.2007.02286.X

Kumar, R., Surendran, P. K., and Thampuran, N. 2010. Rapid quantification of Salmonella in seafood by realtime PCR assay. J. Microbiol. Biotechnol. 20(3): 569573. 
Kumar, H. S, Sunil, R., Venugopal, M. N., Karunasagar, I. and Karunasagar, I. 2003. Detection of Salmonella spp. in tropical seafood by polymerase chain reaction. Int. J. Food Microbiol. 88, 91-95. doi: 10.1016/S01681605(03)00144-2

Lungu, B., Waltman, W. D., Berghaus, R. D., and Hofacre, C. L. 2012. Comparison of a Real-Time PCR Method with a Culture Method for The Detection of Salmonella enterica Serotype Enteritidis in NAturally Contaminated Environmental Samples from Integrated Poultry Houses. [Research Note]. J. Food Prot. 75(4): 743-747. doi: doi:10.4315/0362028X.JFP-11-297

Mackay, I. M. 2004. Real-time PCR in the microbiology laboratory. Clinical Microbiology and Infection. 10(3): 190-212.

Mafu, A. A., Pitre, M., and Sirois, S. 2009. Real-time PCR as a tool for detection of pathogenic bacteria on contaminated food contact surfaces by using a single enrichment medium. J. Food Prot. 72(6): 1310-1314.

Malorny, B., Paccassoni, E., Fach, P., Bunge, C., Martin, A., and Helmuth, R. 2004. Diagnostic Real-Time PCR for Detection of Salmonella in food. Applied and Environmental Microbiology. 70(12): 7046-7052. doi: 10.1128/aem.70.12.7046-7052.2004

McCabe, E. M., Burgess, C. M., O'Regan, E., McGuinness, S., Barry, T., Fanning, S., and Duffy, G. 2011. Development and evaluation of DNA and RNA realtime assays for food analysis using the hilA gene of Salmonella enterica subspecies enterica. Food Microbiol. 28(3): 447-456. doi: 10.1016/ j.fm.2010.10.012

Rahn, K., De Grandis, S. A., Clarke, R. C., McEwen, S. A., Galán, J. E., Ginocchio, C., and Gyles, C. L. 1992. Amplification of an invA gene sequence of Salmonella typhimurium by polymerase chain reaction as a specific method of detection of Salmonella. Molecular and Cellular Probes. 6(4): 271-279. doi: 10.1016/ 0890-8508(92)90002-f

Soto, S. M., Rodríguez, I., Rodicio, M. R., Vila, J., and Mendoza, M. C. 2006. Detection of virulence determinants in clinical strains of Salmonella enterica serovar Enteritidis and mapping on macrorestriction profiles. J. of Medical Microbiology. 55(4): 365-373. doi: 10.1099/jmm.0.46257-0

Techathuvanan, C., Draughon, F. A., and D'Souza, D. H. 2011. Comparison of reverse transcriptase PCR, reverse transcriptase loop-mediated isothermal amplification, and culture-based assays for Salmonella detection from pork processing environments. J. Food Prot. 74(2): 294-301. doi: 10.4315/0362-028x.jfp-10-306

Voogt, N., Raes, M., Wannet, W., Henken, A., and van de Giessen, A. 2001. Comparison of selective enrichment media for the detection of Salmonella in poultry faeces. Lett. Appl. Microbiol. 32: 89 - 92.

Wilkins, W., Waldner, C., Rajic, A., McFall, M., Muckle, A., and Mainar-Jaime, R. C. 2010. Comparison of bacterial culture and real-time PCR for the detection of Salmonella in grow-finish pigs in Western Canada using a Bayesian approach. Zoonoses Public Health, 57 (Suppl 1): 115-120. doi: 10.1111/j.18632378.2010.01365.x

Zhang, G., Brown, E. W., and Gonzalez-Escalona, N. 2011. Comparison of Real-time PCR, Reverse Transcriptase Real-time PCR, Loop-mediated Isothermal Amplification and FDA Conventional Microbiological Method for the Detection of Salmonella spp. in Produce. Appl. Environ Microbiol: aheadofprint. doi: 10.1128/aem.00520-11 